\title{
PERLINDUNGAN HUKUM BAGI PENDIDIK DAN TENAGA KEPENDIDIKAN PADA JALUR PENDIDIKAN NON FORMAL (PTK PNF) MELALUI LKBH
}

\author{
Hendra Nurtjahjo'
}

\begin{abstract}
Abstrak
Providing legal assistance and protection of PTK PNF profession in the field currently run by some LKBH (Institute Consultation and Legal Aid) is appointed by the Directorate of PTK PNF, the Ministry of National Education. At the point of formal education, teachers and lecturers, it was clear the program and the protection of lawful rights, whereas in non-formal education, legal protection mechanisms just have recently established. Recognizing (identification) and collected cases faced by PTK PNF is an important step would be to run the initial efforts for their legal protection. Then, as a guideline for assignment $L K B H$ protection is needed also explain the mechanism of the flow chart handling cases / matters concerning the profession PTK PNF. With how to recognize and understand the case and see the flow chart case handling mechanism, it will be easier LKBH run its activities in protecting the legal rights of PTK PNF profession.
\end{abstract}

Kata kunci:bantuan hukum, tenaga pendidik, kependidikan, lkbh

\section{Pendahuluan}

\section{A. Latar Belakang}

Undang-Undang Nomor 20 Tahun 2003 tentang Sistem Pendidikan Nasional merupakan landasan hukum yang mengatur secara umum kegiatan pendidikan nasional dalam sebuah sistem, dan merupakan dasar bagi pemerintah, baik pusat maupun daerah, dalam melakukan kegiatan bidang pendidikan, baik pendidikan formal maupun pendidikan non formal.

Dalam pelaksanaan pendidikan non formal sering kali terjadi permasalahan/konflik antara pendidik, ${ }^{2}$ tenaga pendidikan dengan

\footnotetext{
${ }^{1}$ Penulis adalah dosen tetap pada Fakultas Hukum Universitas Indonesia. Alamat korespondensi: hendramiska@yahoo.com.
} 
berbagai pihak terkait, maupun permasalahan/konflik antara setiap pendidik dan tenaga kependidikan pendidikan non formal dengan administrasi pemerintahan baik di pusat maupun di daerah. Oleh sebab itulah secara spesifik ada satu pasal dalam UU No. 20 Tahun 2003 yaitu pada pasal 40 (d) yang menyebutkan dibutuhkannya perlindungan hukum bagi pendidik dan tenaga kependidikan dalam satu wadah sistem pendidikan nasional. Dalam hal ini tentu saja mencakup pendidikan dan tenaga pendidikan pada pendidikan non formal.

Dengan adanya permasalahan/konflik bidang pendidikan non formal seperti disebutkan di atas yang tentunya melibatkan Direktorat PTK PNF (Pendidik dan Tenaga Kependidikan Pendidikan Non Formal) Departemen Pendidikan Nasional, maka Sub Direktorat Penghargaan dan Perlindungan (Harlindung) sesuai dengan tugas pokok dan fungsinya, harus memberikan perhatian terhadap pemberian bantuan hukum yang diperlukan bagi PTK PNF, sebagai upaya perlindungan bagi hak-hak mereka sebagai pekerja (tutor, fasilitator, instruktur kursus, laboran, dan pendidik atau guru non formal lainnya).

Untuk menjalankan tugas pokok dan fungsinya dalam perlindungan dan juga secara spesifik membentuk sarana pemberian bantuan hukum, Sub Direktorat Harlindung memerlukan penelitian untuk membentuk wadah yang tepat bagi perlindungan hak-hak hukum dari PTK PNF. Dengan adanya penelitian untuk membentuk cara, sarana dan wahana perlindungan tersebut diharapkan dapat membantu dan mempermudah PTK PNF untuk mengambil langkah-langkah dalam dalam penyelesaian masalah/konflik bidang pendidikan non formal, serta memberikan posisi yang jelas sampai sejauh mana kedudukan dan hak-hak mereka.

Pemberian penghargaan, perlindungan, dan kesejahteraan PTK PNF adalah upaya yang dilakukan oleh pemerintah pusat dan daerah dalam rangka peningkatan mutu, daya saing, dan pencitraan publik serta kesejahteraan PTK PNF, sehingga dapat melaksanakan tugas pokoknya secara profesional dan bermartabat. Pembinaan dan Peningkatan mutu PTK PNF tidak pernah lepas dari pentingnya perlindungan profesi bagi PTK PNF.

Pembentukan 33 LKBH di Tingkat Propinsi (Ditunjuk oleh Direktorat PTK PNF dengan rekomendasi dari Dinas Pendidikan/

2 Istilah pendidik dan tenaga kependidikan adalah istilah yang dipakai untuk menyebut profesi para tutor, fasilitator, pengajar pendidikan anak usia dini, instruktur kursus dll, yang merupakan para guru non formal yang bergerak di lapangan pendidikan luar sekolah, yang sekarang dinamakan jalur pendidikan non formal. 
BPKB) merupakan suatu conditio sine qua non bagi penanganan masalah hukum PTK PNF. Di Tingkat Pusat, dalam kemitraan dengan Direktorat PTK PNF, telah ditunjuk LKBH Pusat yang menjadi 'semacam koordinator' bagi LKBH-LKBH wilayah yang secara spesifik maupun attached to (melekat pada) LKBH lainnya dalam menangani kasus-kasus yang berkenaan dengan profesi PTK PNF.

Dalam hal ini harus kita pahami dan kita sadari bahwa Visi untuk membentuk "Pendidik dan Tenaga Kependidikan Pendidikan Nonformal yang Profesional dan Bermartabat" tidak akan pernah tercapai, apabila tidak ada kesejahteraan, perlindungan dan penghargaan atas hak-hak profesi PTK PNF. Setinggi apapun kualitas PTK PNF, jika perlindungan hak-hak dan kesejahteraannya rendah, maka pastilah kinerjanya akan terganggu.

Perlindungan hak-hak, penghargaan, dan kesejahteraan profesi PTK PNF membutuhkan keberadaan LKBH, tidak hanya pada tingkat daerah, tetapi juga di tingkat pusat, yang berfungsi sebagai pendamping, pembela, mediator, rekonsiliator (advokasi), pembuat perangkat perlindungan bagi PTK PNF. Terbentuknya tatanan organisasi LKBH Tingkat Pusat yang tugas utamanya agak lebih spesifik, yaitu, "mengkoordinir" LKBH dari 33 Propinsi dan berfungsi sebagai perpanjangan tangan dalam pengembangan kebijakan Pusat, diseminasi informasi, dan turut pula mengkaji dan merancang perangkat peraturan yang berkenaan dengan profesi PTK PNF.

Oleh sebab itu diperlukan penelitian komprehensif mengenai kasus-kasus yang menjadi bahan-bahan yang dikompilasi LKBH tingkat pusat, dan dapat digunakan menjadi referensi penting bagi LKBH dan Direktorat Harlindung, serta penyusunan pedoman pemberian bantuan hukum yang akan dilaksanakannya. Dalam hal ini akan dicermati beberapa hal, antara lain: Kasus-kasus yang menonjol, dan bentuk Pedoman/Mekanisme kerja dari LKBH (sebagai mekanisme penyelesaian kasus di internal LKBH), serta sedapat mungkin merancang kode etik bagi pendidik dan tenaga kependidikan pada jalur pendidikan non formal.

\section{B. Maksud dan Tujuan}

Penelitian ini dimaksudkan untuk mengidentifikasi (compiling) kasus-kasus (actual cases) dari profesi PTK PNF dan menyusun bagan alir pemberian bantuan hukum yang diperlukan oleh LKBH dalam penyelesaian permasalahan/konflik pada profesi PTK PNF sebagai 
pedoman dalam internal LKBH yang menangani kasus-kasus PTK PNF.

Sedangkan tujuan yang hendak dicapai dari kegiatan ini adalah (1). teridentifikasinya kasus-kasus PTK PNF (kompilasi kasus), dan (2). tersusunnya bagan alir pemberian bantuan hukum sebagai bahan pegangan internal penyelesaian kasus di internal $\mathrm{LKBH}$, sebagai lembaga perlindungan dalam proses penyelesaian masalah/konflik bidang PNF.

\section{Sasaran}

Sasaran dari kegiatan ini adalah teridentifkasinya Kasus-kasus PTK PNF dan tersusunnya bagan alir pedoman pemberian bantuan hukum bidang PNF yang akan menjadi pegangan bagi $\mathrm{LKBH}$, dan akan menjadi referensi penting bagi Direktorat PTK PNF dalam menjalankan misi perlindungan hukum bagi PTK PNF.

Disamping itu perancangan perangkat perlindungan hukum juga disertai dengan perangkat perlindungan etik secara memadai. Oleh sebab itu dalam penelitian ini juga dibahas alasan diperlukannya Kode Etik bagi pendidik dan tenaga kependidikan dalam jalur pendidikan non formal.

D. Keluaran yang diharapkan.

Ada dua keluaran atau output yang diharapkan dari adanya kegiatan penelitian ini:

1) Tersusunnya Kompilasi Kasus-kasus PTK PNF yang akan menjadi bahan atau referensi bagi LKBH Pusat dan Direktorat Harlindung PTK PNF dalam memahami kasuskasus khas yang sering dialami PTK PNF;

2) Tersedianya suatu bagan alir pedoman pemberian bantuan hukum bidang PNF (sebagai bahan perbandingan dalam penyelesaian kasus di internal LKBH).

\section{E. Metode Penelitan}

Tujuan utama dari penelitian ini adalah untuk mengidentifikasi kasus-kasus yang seringkali muncul berkenaan dengan profesi pendidik dan tenaga kependidikan pada jalur pendidikan non formal (PTK PNF). Kasus-kasus yang diurai dalam bentuk wawancara ini kemudian dikompilasi atau dikumpulkan secara sistemik dan diuraikan 
(deskriptif) yang kemudian diurai analisisnya untuk mendapatkan benang merah dari esensi kasus tersebut. Adapun pembuatan bagan alir merupakan pelengkap yang akan dapat menjadi pegangan bagi para petugas LKBH yang menangani kasus-kasus PTK PNF yang akan terus bermunculan.

Berkenaan dengan tujuan tersebut, penelitan ini menggunakan metode wawancara sederhana dengan cara pengumpulan data melalui instrumen wawancara yang terstruktur untuk mendapatkan input bagi kasus-kasus yang real terjadi di lapangan. Hasil wawancara/melalui kunjungan singkat ini kemudian dideskripsikan dan kemudian dianalisis untuk kemudian diklasifikasi guna mendapatkan esensinya. Studi dokumen melengkapi penelitian ini untuk mendapatkan masukan bagi pembuatan bagan alir dan juga analisis awal keberadaan dan citacita dari PTK PNF.

\section{F. Wilayah Survey/Kunjungan Dialogis}

Wilayah survei pekerjaan Penyusunan Naskah Buku Kompilasi Kasus dan Penyusunan Pedoman /Bagan Alir Mekanisme Pemberian Bantuan Hukum Bidang Pendidikan Non Formal ini meliputi:

1. Malang (Jawa Timur);

2. Bandung (Jawa Barat);

3. DI. Jogyakarta;

4. DKI Jakarta.

Keempat wilayah ini dipilih berdasarkan situasi dan kondisi yang berkenaan dengan waktu kunjung, biaya perjalanan dan juga target kualitatif untuk menghasilkan naskah kompilasi kasus yang memadai dan rancangan bagan alir penanganan kasus yang memadai.

\section{Kasus-Kasus Hukum Dan Perlindungan Profesi Ptk Pnf}

\section{A. Pengantar}

Sistem pendidikan nasional dirancang sebagai upaya untuk mencerdaskan kehidupan bangsa. Dengan demikian, seluruh warga negara Indonesia memiliki hak atas pendidikan tanpa terkecuali. Hal ini secara eksplisit telah dituangkan dalam Amandemen UndangUndang Dasar Negara Republik Indonesia tahun 1945 yang mengamanatkan pentingnya pendidikan nasional, yang secara khusus 
tercantum pada pasal 31 sebagai berikut: ${ }^{3}$ Pasal 31 Ayat (1) "Setiap warga negara berhak mendapatkan pendidikan". Pasal 31 Ayat (2) "Setiap warga negara wajib mengikuti pendidikan dasar dan pemerintah wajib membiayainya".

Sementara itu, pasal 5 ayat 1 Undang-Undang No. 20 Tahun 2003 tentang Sistem Pendidikan Nasional juga menyebutkan bahwa setiap warga negara mempunyai hak yang sama untuk memperoleh pendidikan yang bermutu. Untuk memenuhi hak warga negara inilah pendidikan diselenggarakan dalam tiga jalur, yaitu formal, nonformal, dan informal. ${ }^{4}$

Kelahiran jalur pendidikan nonformal dalam sisitem pendidikan nasional di Indonesia, tidak bisa dilepaskan dari kebutuhan bangsa Indonesia akan layanan pendidikan yang lengkap pada jalur nonkonvensional (diluar sistem persekolahan). Apabila diletakkan Proklamasi Kemerdekaan RI sebagai titik mula sejarah bangsa Indonesai, maka dapat dikatakan bahwa kelahiran institusi pendidikan nonformal adalah untuk memenuhi tuntutan tersedianya layanan pendidikan warga negara diluar sistem sekolah. ${ }^{5}$ Dengan keterbatasan daya jangkau sekolah dan ketetatan prasyarat input maupun proses pendidikan di persekolahan, maka kehadiran pendidikan nonformal sebagai sebuah institusi adalah sebuah keniscayaan. ${ }^{6}$

Secara politis dan yuridis formal, kedudukan pendidikan nonformal sebagai pranata didukung oleh Undang-Undang Nomor 20 tahun 2003 tentang Sistem Pendidikan Nasional. Pasal 13 ayat (1) UU No. 20 tahun 2003 tersebut menyatakan bahwa jalur pendidikan di Indonesia terdiri atas pendidikan formal, pendidikan nonformal, dan pendidikan informal yang dapat saling melengkapi dan memperkaya. Selanjutnya pada pasal 26 (ayat 1) disebutkan bahwa pendidikan nonformal diselenggarakan bagi warga masyarakat yang memerlukan layanan pendidikan yang berfungsi sebagai pengganti, penambah, dan

${ }^{3}$ Widya Ayu Puspita, Pembinaan PTK-PNF Sebagai Upaya Peningkatan Kualitas SDM, Jurnal Ilmiah VISI PTK-PNF, Vol.2, No.1-2007.

${ }^{4}$ Ibid., hal. 28.

${ }^{5}$ Lihat eksplorasi lebih jauh dalam tulisan Sodio A. Kuntoro, Pengembangan Paradigma Baru Keilmuan dan Kelembagaan Pendidikan Non Formal. Jurnal Ilmiah VISI PTK PNF, Vol. 3 No. 1 2008, hal. 66.

${ }^{6}$ Widya Ayu Puspita Op. Cit., hal. 28. 
atau pelengkap pendidikan formal dalam rangka mendukung pendidikan sepanjang hayat [ayat (1)]. ${ }^{7}$

Sebagai pelengkap, penambah, dan atau pengganti pendidikan formal, pendidikan nonformal memiliki peran yang sama pentingnya atau bahkan lebih strategis dibanding pendidikan formal karena melalui jalur pendidikan nonformal seseorang akan memperoleh pendidikan secara lebih komprehensif terutama didalam menghadapi dan menyelesaikan segala macam permasalahan kehidupan. Mengingat arti penting ini, pelayanan pendidikan nonformal hendaknya dapat dilaksanakan secara optimal, bermutu, efisien, dan efektif serta dapat dipertanggungjawabkan secara material dan spiritual. Oleh karena itu, perlu banyak upaya yang dilakukan untuk meningkatkan mutu layanan pendidikan nonformal. ${ }^{8}$

Pelaksanaan pelayanan pendidikan non formal yang optimal dan peningkatan mutunya tidak mungkin tidak bergantung pula dari penghargaan dan perlindungan bagi para pelaksananya, ${ }^{9}$ yaitu para pendidik dan tenaga kependidikan pendidikan non formal. Perlindungan dan penghargaan bagi PTK PNF ini turut menentukan sukses tidaknya pelayanan pendidikan non formal di lapangan. Oleh karena itu program pemberian bantuan hukum bagi PTK PNF adalah merupakan adalah bagian penting dari perlindungan profesi PTK PNF yang perlu mendapat perhatian khusus.

Dengan adanya penghargaan dan perlindungan yang diberikan secara optimal kepada PTK-PNF, maka akan tercipta rasa aman bagi mereka dalam melaksanakan tugasnya. Selain itu pemberian Perlindungan hukum terhadap PTK-PNF akan menjamin terpenuhinya hak-hak PTK-PNF, sehingga pada akhirnya akan meningkatkan profesionalisme dan kesejahteraan mereka, dan ini tentu saja akan berpengaruh terhadap pencapaian mutu Pendidikan Non Formal dan mutu Pendidikan secara luas.

${ }^{7}$ Ibid., hal. 28.

${ }^{8}$ Ibid., hal. 29.

${ }^{9}$ Mengenai Percepatan Peningkatan Kompetensi Lihat tulisan Chairudin Samosir (Dosen Setia Budi Mandiri, Medan) tentang Tutor Inti sebagai solusi percepatan peningkatan kompetensi Tendik. Lihat juga tulisan Harina Yuhety, Yusufhadi Miarso, dan Anisah Basalemah tentang Indikator Mutu Program Pendidikan Sepanjang Hayat (Universitas Negeri Jakarta, 2008). 


\section{B. Kondidisi Pendidik dan Tenaga Kependidikan PNF Saat ini}

Secara umum, mencerdaskan kehidupan bangsa bukan hanya tugas pendidikan formal saja, tetapi pendidikan nonformal memiliki peran dan fungsi yang strategis sesuai amanat UU NO.20 Tahun 2003 tentang Sistem Pendidikan Nasional, Pasal 26, yang menyatakan bahwa pendidikan nonformal diselenggarakan oleh warga masyarakat yang memerlukan layanan pendidikan yang berfungsi sebagai pengganti, penambah, dan/atau pelengkap pendidikan formal dalam rangka mendukung pendidikan sepanjang hayat. Selanjutnya, pendidikan nonfromal menurut Suryadi (2007) melalui kebijakan pembangunan pendidikan nonformal disebutkan sebagai program yang dapat mengatasi kegagalan pendidikan formal pada masa lalu, masa sekarang, masa datang, dan setiap masa. Artinya, kehadiran pendidikan nonformal dimasyarakat membantu masyarakat bangkit dari berbagai keterpurukan, kebodohan, ketertinggalan dan kemiskinan.

Melihat fenomena tersebut, peningkatan profesionalisme tenaga pendidik dan kependidikan nonformal merupakan sebuah keniscayaan dalam mencapai pendidikan yang berkualitas atau pendidikan untuk semua (education for all). ${ }^{10}$ Yang menjadi persoalan adalah bagaimana tugas yang begitu besar dan kompleks dalam zona pendidikan nonformal ini dapat diselenggarakan melalui pusat-pusat kegiatan belajar yang ada dimasyarakat, sementara tenaga pendidikan dan kependidikannya masih memiliki banyak kelemahan baik dilihat dari kompetensi, jumlah, maupun komitmen lain yang berkaitan dengan kebutuhan belajar masyarakat. ${ }^{11}$

Pada tahun 2007, Depdiknas menetapkan program prioritas, yakni penuntasan wajib belajar 9 tahun dan penuntasan buta aksara. Dengan demikian guna mewujudkan capaian target sasaran, diperlukan pendidik dan tenaga kependidikan (PTK) yang tidak hanya pada jalur formal saja, namun juga PTK pada jalur nonformal. Kondisi PTK-PNF selama ini masih sangat membutuhkan dukungan pembinaan dari

${ }^{10}$ Peningkatan Profesionalitas ini dapat dilakukan dengan membangun karakter PTK PNF melalui peningkatan Kompetensi Personal dan social. Lihat tulisan Harun Al Rasyid, Membangun Karakter PTK-PNF melalui Peningkatan Kompetensi Personal dan Sosial, Jurnal Ilmiah VISI PTK-PNF, Vol.3, No.1, 2008.

${ }^{11}$ S. Wisni Septiarti \& Mulyadi, Memaknai Kembali Peningkatan Profesionalisme Tenaga Pendidik Pendidikan Nonfrmal, Jurnal Ilmiah VISI PTK-PNF, Vol.2, No.2-2007, hal. 22. 
Pemerintah Pusat maupun Daerah sehingga PTK-PNF dapat juga membantu percepatan penuntasan wajar buta diknas dan penuntasan buta aksara. Disamping itu program pendidikan kesetaraan dapat dilaksanakan diberbagai tempat yang sudah ada, baik milik pemerintah, masyarakat maupun pribadi, seperti gedung sekolah, Pusat Kegiatan Belajar Masyarakat (PKBM), rumah ibadah, pusat-pusat majelis taklim, balai desa, kantor organisasi-organisasi kemasyarakatan, rumah penduduk dan tempat-tempat lain yang layak juga sangat membutuhkan layanan tenaga pendidik dan kependidikan. $^{12}$

Menurut data yang diperoleh Ditjen PMPTK tahun 2007, terdapat sekitar satu juta pendidik dan tenaga kependidikan nonformal, jumlah yang tidak sedikit. Mereka terdiri dari tutor keaksaraan, tutor kesetaraan, pamong belajar, tenaga lapangan pendidikan masyarakat, instruktur, penilik pendidikan luar sekolah, pendidik pendidikan anak usia dini, dan lain-lain. Para pendidik dan tenaga kependidikan nonformal ini tersebar diseluruh lambaga-lembaga pendidikan nonformal baik di perkotaan maupun di pedesaan. Sampai dengan tahun 2006 mereka berhadapan dengan sekitar 12,7 juta orang penduduk usia diatas 15 tahun buta aksara, ratusan ribu anak putus sekolah, jutaan anak usia dini belum mencicipi pendidikan, dan jutaan pemuda usia produktif tidak memiliki ketrampilan . Apabila kelompok tersebut dibiarkan tidak tersentuh oleh kehadiran tenaga pendidikan dan kependidikan yang bermutu, akan bertambah deretan panjang sumber daya manusia Indonesia yang bermutu rendah dan pada saatnya akan menjadikan Indonesia semakin terpuruk dalam percaturan global. ${ }^{13}$

Ada perbedaan yang significant antara pengertian 'Pendidik' dan 'Tenaga Kependidikan' yang harus dipahami secara jernih oleh kalangan yang terlibat dalam pemberdayaan PTK PNF kita.Begitu pula hendaknya kalangan ahli hukum atau lawyers yang bekerja untuk memperjuangkan PTK PNF. Hal ini penting agar setiap LKBH dan setiap orang yang concern dengan perjuangan PTK PNF untuk meningkatkan sumber daya manusia Indonesia, tidak salah kaprah dalam membela hak dan kepentingan-kepentingan mereka. Pengertian 'Pendidik' dan 'Tenaga Kependidikan' secara simplistis tapi mengena adalah sebagai berikut: Pendidik adalah petugas/orang/warga

\footnotetext{
${ }^{12}$ Ibid., hal. 23.

${ }^{13}$ Ibid., hal. 23.
} 
masyarakat yang langsung berhadapan dengan peserta didik atau warga belajar, dalam rangka melakukan proses pembelajaran. Tenaga Kependidikan adalah petugas/orang/lembaga/warga masyarakat yang memfasilitasi proses kegiatan pembelajaran dan tidak berhadapan langsung dengan peserta didik/warga belajar dalam suatu proses ajar mengajar $/^{14}$

Berikut ini dapat kita lihat data terakhir keberadaan PTK PNF yang selama ini bertugas secara riil di lapangan. PTK-PNF yang berstatus PNS adalah Pamong Belajar ${ }^{15}$ (PB) dan Penilik. Sedangkan PTK-PNF yang tidak berstatus PNS adalah tutor, fasilitator, fasilitator desa intensif (FDI), tenaga lapangan dikmas (TLD), nara sumber teknis, Pendidik PAUD, dan sebagainya. Jumlah PTK-PNF pada status keadaan September 2007 dapat dilihat pada tabel berikut. (Hal. 19 Profil Direktorat PTK PNF).

${ }^{14}$ Definisi sederhana tersebut dapat menjelaskan perbedaan yang significant antara pendidik dan tenaga kependidikan. Definisi didapat dari hasil wawancara dengan Bapak Abubakar, Kasubdit Tendik, Diknas.

${ }^{15}$ Eksplorasi lebih jauh tentang kegiatan Pamong Belajar ini dapat dilihat dalam uraian artikel Melati Indri Hapsari tentang Pengembangan dan Peningkatan Kinerja Pamong Belajar/Sanggar Kegiatan Belajar (P2PNFI Regional II Semarang). 
Data Ketersediaan PTK-PNF (Status September 2008)

\begin{tabular}{|l|l|c|c|}
\hline \multirow{2}{*}{ No } & \multicolumn{2}{|c|}{ Jenis PTK-PNF } & \multicolumn{2}{|c|}{ Jumlah } \\
\cline { 3 - 4 } & & 2008 & 2007 \\
\hline 1 & Pamong Belajar & 3.599 & 4.345 \\
\hline 2 & Penilik & 7.161 & 7.027 \\
\hline 3 & Tenaga Lapangan Dikmas/TLD & 5.135 & 5.190 \\
\hline 4 & Pendidik PAUD & 40.361 & 24.481 \\
\hline 5 & Tutor Paket A Setara SD & 6.105 & 4.174 \\
\hline 6 & Tutor Paket B Setara SMP & 33.255 & 22.818 \\
\hline 7 & Tutor Paket C Setara SMA & 12.582 & 8.498 \\
\hline 8 & Tutur keaksaraan Fungsional & 15.584 & 9.187 \\
\hline 9 & Fasilitator Desa Intensif & - & - \\
\hline 10 & Instruktur Kursus & 6.881 & 7.665 \\
\hline \multicolumn{2}{|r|}{ Jumlah } & 130.667 & 93.385 \\
\hline
\end{tabular}

Keterangan: Berdasarkan pemutakhiran data, jenis ketenagaan yang terkumpul secara individu yakni Pamong Belajar, Penilik, Tenaga Lapangan Dikmas, dan Pendidik PAUD.

Berbagai permasalahan masih sering dihadapi oleh PTK-PNF tersebut, dimana semestinya mereka mendapat jaminan perlindungan berdasarkan Undang-undang. Pada kenyataannya, kondisi ketidaknyamanan masih terus dialami oleh PTK-PNF tanpa adanya sistem perlindungan yang memadai. Pihak PTK-PNF belum banyak memahami apa itu perlindungan dan bagaimana perlindungan itu dapat dilaksanakan.

Mengikuti UU No. 14 tahun 2005 tentang Guru dan Dosen, perlindungan terhadap PTK-PNF dimaksud meliputi perlindungan hukum, perlindungan profesi, serta perlindungan keselamatan dan kesehatan kerja. Termasuk juga di dalamnya, adalah perlindungan atas Hak atas Kekayaan Intelektual atau HaKI. Rencana Aksi Perlindungan PTK-PNF dalam hal ini diperlukan agar seluruh kegiatan yang mengarah kepada perluasan perlindungan PTK PNF lebih tertata dan dapat terlaksana dengan efektif dan efisien.

\section{Isu Strategis Dalam Perlindungan PTK PNF}

Program-program PNF tidak dibatasi oleh jenjang, orientasi belajarnya bersifat praktis, fleksibel dan jangka pendek. Program pembelajaran merupakan respon dari kebutuhan mendesak dari masyarakat dan tidak berorientasi pada ijazah. Dalam proses 
belajarnya, pendidikan nonformal lebih menekankan pada beberapa prinsip seperti: menempatkan warga belajar sebagai subyek yang aktif, menekankan pada kebutuhan warga belajar, menggunakan pendekatan partisipatif sejak persiapan/perencanaan program belajar, pelaksanaan program pembelajaran sampai dengan evaluasi kemajuan belajarnya. ${ }^{16}$

Implementasi program pendidikan non formal yang tidak terlepas dari keragaman sosial budaya, memposisikan keberadaan dan peran PTK PNF semakin strategis. Dengan harapan proses transformasi nilai-nilai keragaman sosial budaya menjadi khasanah pembelajaran yang aktual bagi warga belajar. ${ }^{17}$

Pandangan masyarakat terhadap eksistensi pendidik dan tenaga kependidikan nonformal tidak sekuat bila dibandingkan pandangan mereka terhadap pendidik dan tenaga kependidikan pendidikan formal sehingga memakai dan meningkatakan profesionalisme dan mutu pendidik dan tenaga kependidikan nonformal ini bukanlah sesuatu yang mudah untuk dilakukan. ${ }^{18}$

Berdasarkan berbagai keterangan dan terutama dari buku pedoman pemberian bantuan hukum oleh LKBH yang disusun oleh Direktorat PTK PNF pada pertemuan di Bali pada Tahun 2007, dapat diidentifikasi beberapa isu strategis bagi perlindungan profesi PTK PNF.

Adapun beberapa isu strategis tersebut adalah sebagai berikut:

- PHK yang tdk sesuai dengan peraturan;

- Pemberian Imbalan yg tdk wajar/tdk layak;

- Pembatasan dalam penyampaian opini;

- Pelecehan Profesi PTK PNF;

- Hambatan hambatan lain PTK PNF dalam melaksanakan tugas;

- Permasalahan di sekitar kontrak kerja/SK Pengangkatan;

- Masalah jaminan untuk menjadi PNS.

${ }^{16}$ Ibid., hal. 24.

${ }^{17}$ Muktiono Waspodo, Peran PTK-PNF dalam Menghadapi Keragamaan Sosial Budaya (Sebuah Perenungan Seabad Kebangkitan Nasional), Jurnal Ilmiah VISI PTK-PNF, Vol.3, No.1, 2008. Hal. 22.

${ }^{18}$ Ibid., hal. 25. 
Tujuh point/hal yang tercatat sebagai isu-isu strategis PTK PNF tersebut menyangkut isu strategis yang menjadi benang merah dari permasalahan yang muncul di lapangan.

\section{Kasus-kasus yang ditemukan di Lapangan/Wilayah Survey}

Sebagaimana telah dijelaskan pada Bab pendahuluan bahwa pelaksanaan kegiatan Penyusunan Naskah Kompilasi Kasus Hukum dan pembuatan bagan alir sebagai pedoman Pemberian Bantuan Hukum Bidang Pendidikan Non Formal ini, diperlukan langkahlangkah koordinasi, dan konsultasi. Sehingga keluaran kegiatan ini dapat mencapai hasil optimal yang diharapkan.

Pada penelitian ini tim peneliti mengkoordinasikan pelaksanaan kegiatan pendahuluan penelitian dengan Tim Teknis pada Sub Direktorat Harlindung untuk melihat kemungkinan peta permasalahan hukum secara umum dari perspektif SubDit Harlindung, Direktorat PTK PNF. Peneliti juga berkonsultasi dalam hal daerah survey yang akan dikunjungi untuk memastikan langkah penelitian ini betul-betul dapat memperoleh informasi yang berguna bagi program perlindungan hukum kepada PTK PNF di masa depan.

Dalam tahap pelaksanaan penelitian ini, ada beberapa hal yang dikerjakan sebagai tahapan sebelum mengolah hasil wawancara terstruktur, antara lain:

1. Penelusuran literatur, data dan dokumen;

2. Kunjungan/Survey ke Daerah/Provinsi;

3. Penyusunan bagan alir sebagai pedoman LKBH dalam Pemberian Bantuan Hukum (Operasional);

4. Konklusi dan pelaporan.

Dalam tahapan pelaksanaan di daerah dalam bentuk penjajakan awal maupun kegiatan pendataan, juga dipadukan dengan diskusi dan pembahasan ditingkat pusat, dengan para pejabat yang dicanangkan sebagai contact person yang ada di Direktorat Harlindung. Salah satu hal yang dikembangkan adalah diskusi dengan nara sumber dan pakar di bidang pendidikan non formal, baik secara langsung maupun dengan cara komunikasi telepon.

Pada tahap analisis disajikan data-data permasalahan/konflik hasil temuan di lapangan yang akan disusun dalam format baku yang mudah untuk dipahami dan di update setiap ada perkembangan. Data-data yang sudah dikompilasi selanjutnya akan dipergunakan sebagai masukan dalam analisis. 
Pada tahapan ini berbagai metode analisis akan dipergunakan untuk mengolah data-data yang telah dikumpulkan dan disusun, sehingga keluaran dari analisis ini dapat dipakai sebagai bahan pertimbangan dalam perumusan permasalahan-permasalahan sebagai sesuatu yang harus dicarikan solusinya.

Sesuai dengan Kerangka Kerja, peneliti melaksanakan pekerjaan Penyusunan Konsep alternatif pembuatan bagan alir Pedoman Pemberian Bantuan Hukum Bidang Pendidikan Non Formal, secara simultan berdasarkan ruang lingkup kegiatan dengan tahap-tahap pelaksanaan kegiatan sebagai berikut: 1. Inventarisasi data dan permasalahan, 2. Analisis data dan permasalahan, 3. Perumusan/hasil evaluasi.

\section{Deskripsi Identifikasi/Kompilasi Kasus-Kasus Hukum Hasil Survey}

Berikut ini dideskripsikan hasil wawancara dan penjajakan (uraian masalah dan analisis kajian) yang dilakukan untuk melihat kegiatan yang telah dan sedang ditangani oleh beberapa LKBH di daerah. Hal ini diharapkan menjadi naskah yang terkompilasi dari kasus-kasus hukum yang pada umumnya terjadi pada PTK PNF di seluruh wilayah Negara Kesatuan Republik Indonesia.

\section{Jawa Timur (BKBH Universitas Muhamadiyah Malang) (Hasil Wawancara dengan Bapak Sumali, dkk)}

BKBH (Badan Konsultasi dan Bantuan Hukum Universitas Muhammadiyah Malang), adalah LKBH yang mendapatkan dana Block Grant untuk menjadi Lawyers bagi PTK PNF di Jawa Timur. Kegiatan LKBH Unmu Malang ini berkenaan dengan PTK PNF masih lebih banyak bersifat sosialisasi (penyuluhan) dan mediasi, sedangkan untuk konsultasi dan advokasi (litigasi) sangat jarang dan tidak terdapat banyak kasus/pengaduan dari PTK PNF di lingkungan Jawa Timur (Berdasarkan wawancara dan bahan laporan BKBH JaTim dalam penggunaan block grant tahun lalu).

Pada saat ini LKBH Unmu Malang sedang mempersiapkan bahan untuk melakukan Judicial Review ke Mahkamah Agung berkenaan dengan Peraturan Presiden (Perpres) No. 108 Tahun 2007 tentang Tunjangan Pendidikan sehubungan dengan batas usia pensiun yang berbeda antara penilik dan pengawas. Dalam kasus ini dipersoalkan bahwa ada perbedaan signifikan antara tunjangan Penilik yang lebih kecil daripada tunjangan yang 
diberikan kepada pengawas. Penilaian sebagian pihak ini merupakan suatu kebijakan diskriminatif yang harus segera dibenahi agar tidak menimbulkan kecemburuan sosial dan menyebabkan suasana psikologis yang tidak membawa kepada suasana kenyamanan kerja yang akan berdampak pada proses pendidikan warga belajar non formal.

Ikatan Penilik Indonesia (IPI) sebenarnya akan melakukan mekanisme Banding Administratif (Administratieve Beroep) tetapi hal tersebut luput untuk dilakukan karena telah lewat batas waktu 180 hari kerja. Sehingga tidak dapat direview berdasarkan mekanisme itu. Pada saat ini, pihak hakim agung MA menyatakan bahwa hal tersebut dapat diterima untuk diuji MA (Hal ini baru dalam tahap konsultasi dengan hakim agung Bapak Paulus Effendi Lotulung).

$\mathrm{BKBH} / \mathrm{LKBH}$ Unmu kelihatannya lebih cendrung untuk memperjuangkan konsep dan perangkat hukumnya dulu sebelum kita bergerak untuk melindungi hak-hak PTK PNF. Hal ini kiranya dapat dibenarkan karena dalam beberapa kasus, perlindungan terhadap hak PTK PNF kekurangan payung hukum atau payung hukumnya tidak memadai atau masih bersifat diskriminatif.

\section{Jawa Barat (LKBH UPI Bandung) (Hasil Wawancara dengan Bapak Astim, dkk)}

Fokus kegiatan LKBH UPI (Universitas Pendidikan Indonesia), Bandung pada penggunaan dana block grant tahun 2008 adalah pelayanan advokasi kepada Pendidik dan Tenaga Kependidikan Non Formal (PTK PNF) di Provinsi Jawa Barat. Pelayanan advokasi ini dibatasi perhatiaannya pada profesi Penilik dan Pamong Belajar saja (yang berstatus PNS), dengan dua kabupaten (Subang dan Sumedang) sebagai tempat pengambilan sampel atau penelitian.

Secara umum, LKBH UPI merangkum beberapa masalah PTK PNF yang diperoleh dari penyebaran kuesioner di Propinsi Jawa Barat (khususnya Kabupaten Subang dan Sumedang) sebagai berikut:

1. Belum ada PP yang mengatur secara khusus tentang PNF, Beberapa peraturan yang diskriminatif,dll;

2. LKBH: Belum tersosialisasi keberadaannya, tidak sampai ke kabupaten/kota; 
3. Kurangnya dana opersional, tidak adanya tunjangan fungsional, tidak ada dana monitoring utk PKBM, gaji/honor yang sangat $\mathrm{minim} / \mathrm{kecil}$;

4. Kurangnya pelatihan, kursus pengembangan keterampilan, kurangnya beasiswa untuk melanjutkan sekolah, rekrutmen yg hanya memperhatikan pendidikan formal,dll;

5. Banyaknya gangguan yang bersifat pungutan liar, pemotongan dana bantuan insentif oleh pihak ketiga, perlakuan diskriminatif dari berbagai kalangan, kurangnya dukungan aparat Pemda, gangguan dari kalangan wartawan bodrex.

Langkah yang diambil oleh LKBH UPI dalam mengatasi atau memecahkan masalah yang ditermukan ini adalah dengan cara mediasi. Mediasi yang dimaksudkan disini adalah menyampaikan situasi dan kondisi yang menjadi masalah tersebut kepada Subdin PLS, Dinas Pendidikan Propinsi, dan Kabupaten untuk memperhatikan usulan PTK PNF guna dilanjutkan ke Direktorat PTK PNF dan ke Direktorat PMPTK Depdiknas Pusat.

Beberapa kasus diselesaikan dengan cara memberikan saransaran atau imbauan langsung kepada PTK PNF yang bersangkutan, misalnya imbauan untuk mematuhi PP No. 30/1980 Tentang Peraturan Disiplin PNS.

\section{DI. Yogyakarta (LKBH Universitas Ahmad Dahlan, Jogya) (Hasil Wawancara dengan Bapak Heru Iswandi, dkk)}

Berdasarkan informasi dari Bapak Heru, Ketua LKBH Ahmad Dahlan, Jogja, Selama tahun 2008 boleh dikatakan kasus hukum yang diadvokasi nihil (tidak ada). Untuk Konsultasi hukum dari kalangan PTK PNF sangat sedikit. Menurut Pak Heru, kegiatan LKBH Jogja dari tahun 2006-2008 lebih berfokus pada sosialisasi (penyuluhan dan diseminasi adanya bantuan hukum bagi PTK PNF di Jogja. Tidak adanya advokasi dapat diartikan bahwa tidak ada kasus hukum yang masuk ditangani hingga meja hijau (litigasi/peradilan).

Banyak hal yang sudah dilakukan untuk memberitakan kepada PTK PNF di wilayah Jogja bahwa mereka memiliki LKBH yang dapat membantu mereka untuk memecahkan masalah-masalah hukum yang mereka hadapi. Misalnya, 
membuka kotak pos konsultasi dan advokasi pada beberapa kecamatan dan sudin PLS. Mereka juga membuat kartu harlindung, membuat selebaran yang berisi formulir pengaduan yang dapat dikirimkan ke alamat LKBH yang berada di Jogja. Sosialisasi keberadaan PTK PNF dan adanya LKBH PTK PNF ini juga mereka sampaikan ke beberapa aparat PEMDA, dan menurut pak Heru, kadangkala Bupati-pun tidak tahu adanya PTK PNF apalagi LKBH-nya.

Beberapa kasus yang muncul dan pernah mereka berikan advice (nasehat hukum) dalam konsultasi dengan PTK PNF adalah sebagai berikut:

1. Instruktur Kursus banyak yang dipecat karena tidak ada kontrak kerja;

2. Di lapangan banyak guru non formal tidak punya SK (hanya volunteer);

3. Tidak adanya jaminan kesehatan bagi penilik yang bekerja seharian;

4. Penilik disuruh mengantar surat yang bukan tugas intinya. (pelecehan);

5. Untuk dapat bantuan/insentif banyak syarat formalitas tertentu (sulit);

6. Ijazah paket $\mathrm{C}$ tidak diakui setara dengan SMA, sehingga tidak diterima untuk melamar menjadi calon TNI;

7. Kepres menyatakan Pamong Belajar PNF batas usia pensiunnya dapat diperpanjang 60 tahun, padahal atasan mereka (Bupati/Walikota) bisa mengusulkan untuk diperpanjang sampai 60 tahun.

Menurut pak Heru, UU Ketenagakerjaan tidak bisa diberlakukan kepada PTK PNF karena hampir sebagian besar dari PTK PNF adalah kerja sambilan/paruh waktu, pengabdian, dan rata-rata tidak pernah komplain dengan gaji yang kecil sekalipun.

\section{DKI Jakarta (Kantor Hukum Erfan, Hifni, dan Rekan) (Hasil Wawancara dengan Bapak Hifni)}

Berdasarkan informasi Bapak Hifni Hasan, ada sekitar 4 sampai 5 orang Pendidik PAUD di Jakarta tidak memperoleh honor selama 6 (enam) bulan. Mereka sudah bekerja selama bertahun-tahun sebagai pendidik PAUD. Setelah dikonfirmasi kepada pihak DIKNAS oleh Bpk. Hifni Hasan, pihak DIKNAS 
mengatakan bahwa ternyata ada kesalahan administrasi yang menyebabkan honor 4 sampai 5 orang tersebut belum dibayar. Selama ini sistem pembayaran honor pendidik PAUD dilakukan 3 bulan sekali.

Sampai saat ini belum ada kabar lagi dari pendidik PAUD yang bersangkutan tentang tindak lanjut dari honor yang tidak dibayar tersebut, sehingga Bpk. Hifni Hasan berasumsi bahwa honor 4 atau 5 orang pendidik PAUD tersebut telah dibayar dan permasalahannya telah selesai.

Dalam hal ini terlihat, personil LKBH tersebut tidak melakukan pendekatan jemput bola, artinya perkembangan kasus tidak dipantau dan kontak dengan klien terputus. Padahal untuk PTK PNF yang tidak dibayarkan honornya tersebut amatlah sulit untuk mengontak para petugas LKBH karena kekurangan dana dan kendala psikologis lainnya.

\section{Narasumber Dari Direktorat PTK PNF (Hasil Wawancara dengan Bapak Harizal dan Bapak Abubakar)}

1. Sekitar 2000 orang atau hampir seluruh pendidik non formal di Jakarta, nama-nama mereka sudah masuk dalam data base, akan tetapi mereka belum bisa masuk menjadi calon pegawai negeri sipil. Hal ini disebabkan karena di DKI Jakarta belum ada Dana Alokasi Umum dalam APBD DKI Jakarta. Sedangkan belum adanya Dana Alokasi Umum di DKI Jakarta dikarenakan APBD DKI Jakarta sangat tinggi. Sementara itu, Badan Kepegawaian Negara juga tidak bisa mengangkat mereka karena di era otonomi daerah, wewenang pengangkatan pegawai ada pada pemerintah daerah. Sampai saat ini, jaminan menjadi PNS pagi pendidik non formal di DKI Jakarta masih menjadi persoalan yang belum ada jalan keluarnya sekalipun pembahasan mengenai persoalan ini sudah melibatkan pihak DPRD.

2. Penilik yang tergabung dalam Ikatan Penilik Indonesia (IPI) mengajukan tuntutan yang ditujukan kepada Direktorat PTK PNF agar mengajukan revisi terhadap Keputusan Menteri Pendayagunaan Aparatur Negara Nomor 15/M.PAN/3/2002 khususnya tentang ketentuan batas usia pensiun. Mereka menginginkan agar batas usia 
pensiun mereka disamakan dengan jabatan fungsional (pengawas). Dengan adanya perbedaan batas usia pensiun antara mereka dengan jabatan fungsional (pengawas), mereka seolah-olah diperlakukan diskriminatif.(Harizal).

3. Ada indikasi terjadinya penyalahgunaan anggaran keuangan oleh Penyelenggaran pembelajaran yang telah memperoleh block grant dari Departemen Pendidikan Nasional (kasus NTT). Penyelenggara kegiatan pembelajaran tersebut kemudian dipanggil oleh pihak berwenang/pihak terkait (diknas) untuk menjelaskan hal tersebut. Penyelenggara yang berasal dari (tokoh-tokoh) masyarakat tersebut berusaha ikut melibatkan tutor-tutor yang pada dasarnya hanya melakukan tugas mengajar dan tidak ikut dalam pengelolan keuangan. Para tutor tersebut merasa ketakutan dan akhirnya mereka minta bantuan LKBH utuk mendampingi mereka. Akhirnya LKBH melakukan mekanisme mediasi dan berperan sebagai mediator antar pihak yang saling tuduh dan saling menyalahkan. Baru pada tahap mediasi (belum sampai litigasi ke pengadilan) mereka dipanggil sebagai 'saksi' tapi ternyata tidak terbukti keterlibatan mereka. Persoalan terhenti sampai di mediasi saja. (Abu bakar)

Secara umum dapat diresume, bahwa dari kompilasi kasus hukum yang dikemukakan oleh pelaksana tugas di empat LKBH yang diwawancara, maupun narasumber dari Direktorat PTK PNF sendiri, tidak banyak kasus hukum yang muncul dari kalangan pendidik maupun tenaga kependidikan dalam jalur pendidikan non formal ini. Artinya, sangat kecil kemungkinan terjadinya kasus hukum yang dapat menjadi kasus hukum besar hingga masuk ke ruang pengadilan (litigasi). Pada kenyataannya, hal ini dapat terjadi karena beberapa kemungkinan. Pertama, pada umumnya kalangan pendidik dan tenaga kependidikan dalam jalur pendidikan non formal adalah sukarelawan yang bekerja dengan idealisme, dan tidak terlalu memperhatikan hak-haknya sebagai 'pekerja' Kedua, belum tersosialisasinya keberadaan LKBH di kalangan PTK PNF. Ketiga, belum adanya perhatian yang cukup dari kalangan pemerintah daerah maupun pusat untuk memenuhi hak-hak PTK PNF, sebagaimana yang sudah dimediasikan/ disampaikan oleh LKBH. Keempat, adanya faktor psikososial 
yang menyebabkan tidak sampainya informasi perbaikan dari lapangan ke tingkat pengambil kebijakan.

\section{E. Masalah Fundamental dari Perlindungan dan Pemberian Bantuan Hukum PTK PNF Saat ini}

Materi perlindungan hukum bagi pendidik, termasuk PTKPNF mulai mengemuka dalam UU No. 2 tahun 1989 tentang Sistem Pendidikan Nasional yang diperbaharui dan kemudian diganti dengan UU No. 20 tahun 2003 tentang Sistem Pendidikan Nasional. Penjabaran pelaksanaan perlindungan hukum itu diatur dalam Peraturan Pemerintah No. 38 tahun 1992 tentang arti perlindungan hukum bagi PTK-PNF yang meliputi kepemilikan rasa aman, perlindungan terhadap pemutusan hubungan kerja, dan perlindungan terhadap keselamatan dan kesehatan kerja.

Hal yang menjadi masalah fundamental dalam upaya-upaya untuk melakukan perlindungan profesi dalam bentuk perlindungan hukum dan pemberian bantuan hukum adalah menyangkut soal: 1 . Pemahaman terhadap arti atau makna 'perlindungan', 2. Aksi atau kegiatan untuk mendukung pembuatan perangkat perlindungan yang efektif dan efisien, 3. Mengefektifkan peran masing-masing perangkat organisasi untuk mensosialisasikan (diseminasi) adanya hak-hak PTK PNF yang harus dilindungi dan disuarakan (diaktualisasikan) untuk perbaikan keberadaan profesi PTK PNF.

Hak yang dimiliki PTK-PNF dalam melaksanakan tugas keprofesionalannya, yaitu:

1. Memperoleh penghasilan diatas kebutuhan minimum dan jaminan kesejahteraan sosial;

2. Mendapatkan promosi dan penghargaan sesuai dengan tugas dan prestasi kerja;

3. Memperoleh perlindungan dalam melaksanakan tugas dan hak atas kekayaan intelektual;

4. Memperoleh kesempatan untuk meningkatkan kompetensi pembelajaran untuk memperlancar tugas keprofesionalan;

5. Memperoleh dan memanfaatkan sarana dan prasarana;

6. Memiliki kebebasan dalam memberikan penilaian dan ikut menentukan kelulusan, penghargaan dan/atau sanksi kepada peserta didik;

7. Memperoleh rasa aman dan jaminan keselamatan dalam melaksanakan tugas;

8. Memiliki kebebasan berserikat dalam organisasi profesi; 
9. Memiliki kesempatan dalam berperan menentukan kebijakan pendidikan;

10. Memperoleh kesempatan untuk mengembangkan dan meningkatkan kualifikasi akademik/kompetensi;

11. Memperoleh pelatihan dan pengembangan profesi dalam bidangnya.

Fakta dan kenyataan yang ada di lapangan menunjukkan bahwa kondisi PTK-PNF di seluruh wilayah Indonesia, belum mendapatkan perlindungan hukum secara optimal. Bahkan dalam banyak hal para pendidik dan tenaga pendidikan non formal tidak mengetahui adanya program pemberian perlindungan ini atau bahkan tidak tahu keberadaan asosiasi profesi mereka dan tidak tahu keberadaan LKBH yang ditugasi untuk itu. Beberapa penyebab atau akar permasalahan yang dihadapi antara lain:

1. Belum lengkapnya payung hukum. Belum adanya regulasi yang secara spesifik menjamin perlindungan hukum bagi PTK-PNF, terutama berkaitan dengan produk hukum yang dapat menjamin/melindungi mereka baik dari asosiasi profesi maupun peraturan lain yang memperkuat posisi dari PTKPNF dalam berkarya. Misalnya: yang paling konkrit adalah belum adanya Peraturan Pemerintah (PP) yang mengatur secara khusus tentang Pendidikan Non Formal di Indonesia, sebagai jabaran dari UU Sisdiknas. adanya beberapa peraturan yang diskriminatif dll;

2. Kurangnya sosialisasi pengetahuan, dan pemahaman hukum para PTK-PNF terhadap hak dan kewajiban mereka terutama berkaitan dengan hubungan mereka selaku tenaga kerja dengan pemberi kerja, misalnya mengenai pemutusan hubungan kerja (PHK), pemberian imbalan yang tidak wajar, pembatasan dalam penyampaian pandangan, pelecehan terhadap profesi dan pembatasan/pelarangan lain yang dapat menghambat PTK-PNF dalam melaksanakan tugasnya;

3. Belum meratanya sarana perlindungan hukum (LKBH: Belum tersosialisasi keberadaannya sebagai agen perlindungan hukum bagi seluruh PTK PNF, tidak menjangkau hingga kabupaten/kota dll);

4. Belum memadainya kesejahteraan (kurangnya dana opersional, tidak adanya tunjangan fungsional, tidak ada dana monitoring utk PKBM, gaji/honor yang sangat $\operatorname{minim} /$ kecil, dll); 
5. Belum memadainya pengembangan profesi (Kurangnya pelatihan, kursus pengembangan keterampilan, kurangnya beasiswa untuk melanjutkan sekolah, rekrutmen yg hanya memperhatikan pendidikan formal dII);

6. Banyaknya gangguan dalam menjalankan tugas (pungutan liar, pemotongan dana bantuan insentif oleh pihak ketiga, perlakuan diskriminatif dari berbagai kalangan, kurangnya dukungan aparat Pemda, gangguan dari kalangan wartawan bodrex dII);

7. Belum adanya standardisasi kualifikasi profesi PTK-PNF yang dapat dijadikan acuan dalam melaksanakan advokasi dan perlindungan profesi mereka. Misalnya: yang paling konkrit adalah belum adanya Kode Etik bagi profesi pendidik maupun tenaga kependidikan non formal. Standar kualifikasi untuk penilik, standar kualifikasi untuk seorang pamong belajar yang baik, standar kualifikasi untuk instruktur kursus menjahit dll;

8. Kurangnya pengetahuan PTK-PNF dalam memahami alur (mekanisme) pelaporan/pengaduan dan proses operasional pe-mecahan kasus yang mereka hadapi. Ada dua jalur penyelesaian kasus, yaitu jalur hukum dan jalur etika. Untuk kasus hukum, PTK-PNF melalui jalur Advokasi yang diberikan LBH/BKBH di Indonesia, dan jalur etika melalui jalur badan kehormatan profesi (belum dibuat perangkatnya). Kurangnya pengetahuan dan pemahaman para PTK-PNF dalam menghadapi kasus dan masalah HAKI dan prosedur pemerolehan hak-hak intelektualnya.

Untuk mempermudah pemahaman mengenai masalahmasalah fundamental yang juga dapat menimbulkan masalah hukum, kami sajikan bagan sebagaimana tergambar di bawah ini:

AKAR PERMASALAHAN PTK -PNF (Penyebab Munculnya Masalah Hukum)

\begin{tabular}{|l|l|l|}
\hline No. & \multicolumn{1}{|c|}{ MASALAH } & \multicolumn{1}{|c|}{ KETERANGAN } \\
\hline 1 & $\begin{array}{l}\text { Belum lengkapnya payung hukum } \\
\text { PTK-PNF } \\
\text { (MASALAH HUKUM) }\end{array}$ & $\begin{array}{l}\text { Belum ada PP, Ada } \\
\text { Peraturan yang } \\
\text { diskriminatif }\end{array}$ \\
\hline 2 & $\begin{array}{l}\text { Kurangnya sosialisasi pengetahuan } \\
\text { dan pemahaman hukum }\end{array}$ & $\begin{array}{l}\text { Mengenai hak-hak } \\
\text { dalam PHK, HAKI, }\end{array}$ \\
\hline
\end{tabular}




\begin{tabular}{|c|c|c|}
\hline & (MASALAH HUKUM) & HAM, dll. \\
\hline 3 & $\begin{array}{l}\text { Belum meratanya sarana } \\
\text { perlindungan hukum/Keberadaan } \\
\text { LKBH. } \\
\text { (MASALAH HUKUM) }\end{array}$ & $\begin{array}{l}\text { Penisbahan LKBH } \\
\text { sebagai Pusat } \\
\text { Pengaduan belum } \\
\text { sampai ke tingkat } \\
\text { Kabupaten/Kecamatan }\end{array}$ \\
\hline 4 & $\begin{array}{l}\text { Belum memadainya kesejahteraan } \\
\text { (MASALAH KEBIJAKAN } \\
\text { DEPARTEMEN) }\end{array}$ & $\begin{array}{l}\text { Kurangnya dana } \\
\text { opersional, tidak } \\
\text { adanya tunjangan } \\
\text { fungsional, tidak ada } \\
\text { dana monitoring utk } \\
\text { PKBM, gaji/honor yang } \\
\text { sangat minim/kecil, dll. }\end{array}$ \\
\hline 5 & $\begin{array}{l}\text { Belum memadainya } \\
\text { pengembangan profesi } \\
\text { (MASALAH KEBIJAKAN } \\
\text { DEPARTEMEN) }\end{array}$ & $\begin{array}{l}\text { Kurangnya pelatihan, } \\
\text { kursus pengembangan } \\
\text { keterampilan, } \\
\text { kurangnya beasiswa } \\
\text { untuk melanjutkan } \\
\text { sekolah, rekrutmen yg } \\
\text { hanya memperhatikan } \\
\text { pendidikan formal dll. }\end{array}$ \\
\hline 6 & $\begin{array}{l}\text { Banyaknya gangguan dalam } \\
\text { menjalankan tugas } \\
\text { (MASALAH HUKUM DAN } \\
\text { ETIKA) }\end{array}$ & $\begin{array}{l}\text { Banyaknya pungutan } \\
\text { liar, pemotongan dana } \\
\text { bantuan insentif oleh } \\
\text { pihak ketiga, pelecehan } \\
\text { profesi, perlakuan } \\
\text { diskriminatif dari } \\
\text { berbagai kalangan, } \\
\text { kurangnya dukungan } \\
\text { aparat Pemda, } \\
\text { gangguan dari kalangan } \\
\text { wartawan dll }\end{array}$ \\
\hline 7 & $\begin{array}{lc}\text { Belum adanya } & \text { standardisasi } \\
\text { kualifikasi profesi PTK-PNF } \\
\text { (MASALAH } & \text { KEBIJAKAN } \\
\text { DEPARTEMEN) } & \end{array}$ & $\begin{array}{lr}\begin{array}{l}\text { Belum ada } \\
\text { konkrit }\end{array} & \text { acuan } \\
\text { melaksanakan } & \\
\text { perlindungan } & \text { profesi } \\
\text { mereka; belum } & \text { adanya } \\
\text { Kode Etik, } & \text { Standar } \\
\text { kualifikasi } & \text { untuk } \\
\text { penilik, } & \text { standar } \\
\text { kualifikasi } & \text { untuk } \\
\end{array}$ \\
\hline
\end{tabular}




\begin{tabular}{|l|l|l|}
\hline \multirow{8}{*}{8} & $\begin{array}{l}\text { seorang pamong belajar } \\
\text { yang baik, standar } \\
\text { kualifikasi untuk } \\
\text { instruktur kursus } \\
\text { menjahit dll. }\end{array}$ \\
\hline & $\begin{array}{l}\text { Untuk kasus hukum, } \\
\text { Kurangnya pengetahuan PTK-PNF } \\
\text { dalam memahami mekanisme } \\
\text { pengaduan kasus. } \\
\text { (MASALAH HUKUM) }\end{array}$ & $\begin{array}{l}\text { Advokasi yang } \\
\text { diberikan LBH/BKBH } \\
\text { di Indonesia, dan jalur } \\
\text { etika melalui jalur } \\
\text { badan kehormatan } \\
\text { profesi (belum dibuat } \\
\text { perangkatnya). }\end{array}$ \\
\hline
\end{tabular}

Dari delapan akar permasalahan hukum yang dapat memunculkan berbagai kasus hukum dan sosial lainnya, tiga diantaranya adalah berkaitan dengan kebijakan departemen pendidikan nasional dalam mengatur hal-hal yang menyangkut eksistensi PTK PNF. Adapun lima hal lainnya secara langsung maupun tidak langsung berkenaan dengan masalah hukum dan etika.

\section{F. Keperluan akan Kode Etik Bagi PTK PNF}

Profesionalisme bagi pendidik dan tenaga pendidikan formal maupun nonformal merupakan sebuah kebutuhan yang tidak dapat ditunda-tunda, sering dengan semakin meningkatnya persaingan dan tuntutan yang semakin kompleks. Sebagai profesi, pengembangan kompetensi tenaga pendidik pada pendidikan formal (guru) serta tenaga pendidik dan tenaga kependidikan PNF yang sering disebut pamong, tutor, atau instruktur merupakan sebuah keharusan dalam kerangka perbaikan kualitas hidup manusia. Profesionalisme bagi tenaga pendidik PNF menuntut keseriusan dalam menghayati kompetensi-kompetensinya juga sehingga sesorang dianggap layak melaksanakan sebuah tugas. ${ }^{19}$ Namun demikian semua kompetensi yang dikuasai seorang tenaga pendidik dalam membelajarkan

19 Lihat tulisan Nursam (Mahasiswa SPS UPI) tentang Peningkatan Kemampuan Pendidik PNF dalam Implementasi Pembelajaran, 2008. 
masyarakat tak lepas dari pengaruh dan permasalahan sosiokultural masyarakat yang begitu beragam. ${ }^{20}$

Keberhasilan pelaksanaan peningkatan profesional PTK-PNF dalam rangka meningkatkan mutu pendidikan secara nasional, juga menjadi harapan nyata bagi pembangunan pendidikan. Peningkatan PTK-PNF dapat dilakukan dengan menggunakan berbagai cara yang disarankan melalui arah, starategi, dan kebijakan Direktorat PTK-PNF. Model yang disarankan memiliki karakteristik tersendiri, demikian juga keadaan PTK-PNF dimasing-masing tempat memiliki karakteristik sosiokultural sendiri. Tingkat keberhasilan program pendidikan profesionlisme PTK-PNF sangat bergantung pada pemahaman, kesadaran, keterlibatan, dan upaya sungguh-sungguh dari segenap unsur pelaksana program termasuk didalamnya optimalisasi Tim Akademisi. ${ }^{21}$

Berdasarkan UU No. 14 tahun 2005 tentang Guru dan Dosen, perlindungan terhadap PTK-PNF dimaksud meliputi perlindungan hukum, perlindungan profesi, serta perlindungan keselamatan dan kesehatan kerja. Termasuk juga di dalamnya, adalah perlindungan atas Hak atas Kekayaan Intelektual atau HaKI. Namun demikian, dalam perspektif ilmu hukum, pengertian "perlindungan" yang dimuat dalam UU No. 14 tentang Guru dan Dosen itu kuranglah tepat. Dalam hubungannya dengan klasifikasi genus dan spesies, perlindungan profesi itu adalah genusnya, dimana spesies yang termasuk didalamnya adalah perlindungan hukum dan perlindungan profesi. Sedangkan perlindungan hukum didalamnya terdapat perlindungan K3 (Kesehatan dan Keselamatan Kerja), dan perlindungan Hak atas Kekayaan Intelektual (HAKI/HKI), disamping perlindungan hukum dalam bidang hukum lainnya. Semua itu dimaksudkan untuk perlindungan profesi, dalam hal ini adalah profesi PTK PNF. Namun demikian, harus kita pahami bahwa pendidik dan tenaga kependidikan ini adalah juga merupakan karakter profesi yang memerlukan kode etik profesinya sendiri. Oleh sebab itu dapat dinyatakan bahwa perlindungan profesi itu dilakukan melalui perlindungan hukum dan perlindungan etika (kode etik profesi). Sehinga untuk perlindungan melalui jalur hukum diperlukan perangkat hukum yang memadai, demikian pula perlindungan melalui jalur etika memerlukan perangkat etika yang berupa kode etik dan badan kehormatan etik (sebagai

${ }^{20}$ Widya Ayu Puspita, Op. Cit., hal. 24.

${ }^{21}$ Ibid., hal. 27. 
lembaga yang menegakkan adanya pelanggaran etika). Hal inilah yang harus dipahami secara jernih oleh para pengambil kebijakan dan personil LKBH.

Namun demikian, adalah arif untuk melihat keadaan atau kenyataan yang ada di lapangan. Perlindungan etik melalui kode etik dan pendirian badan kehormatan etik kiranya belumlah diperlukan untuk saat ini. Pertama, karena hal etik masih bisa dipecahkan atau dicarikan jalan keluarnya melalui mekanisme mediasi atau advokasi.

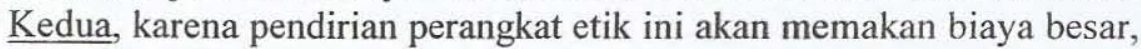
sedangkan kebutuhannya tidak terlalu besar untuk saat ini. Ketiga, mekanisme bantuan hukum (yang dilakukan LKBH) dapat dimanfaatkan untuk ikut membantu permasalahan etik yang ada. Namun kiranya, tidak ada salahnya perangkat tersebut tetap disiapkan sedini mungkin agar segala kelengkapan perlindungan pada jalur etika juga dapat memberikan kontribusi positif bagi perlindungan, dan peningkatan mutu PTK PNF, serta kenyamanan profesional kegiatan pendidikan non formal di semua lini.

Dalam penelitian ini diintrodusir juga dua buah draft kode etik yang diperlukan sebagai bahan dasar bagi terbentuknya Kode Etik Pendidik, dan juga Kode Etik bagi Tenaga Kependidikan dalam dunia Pendidikan Non Formal. Namun demikian karena terbatasnya tempat tidak mungkin untuk ditampilkan disini.

Untuk melengkapi keterangan mengenai pemahaman tentang perlindungan profesi dari perspektif ilmu hukum, maka dibawah ini disajikan sebuah bagan yang menjelaskan jalur, perangkat, dan pelaku dari perlindungan profesi bagi PTK PNF. Dalam hal ini harus dipahami betul bahwa ada perbedaan signifikan antara mekanisme hukum dan etika. 


\begin{tabular}{|c|c|c|c|}
\hline \multicolumn{4}{|c|}{ MEKANISME PERLINDUNGAN PROFESI PTK-PNF } \\
\hline No. & $\begin{array}{c}\text { JALUR } \\
\text { Path/Mechanism }\end{array}$ & $\begin{array}{c}\text { PERANGKAT } \\
\text { Software }\end{array}$ & $\begin{array}{c}\text { PELAKU } \\
\text { Actors }\end{array}$ \\
\hline 1 & HUKUM & $\begin{array}{l}\text { 1. Peraturan } \\
\text { Pemerintah } \\
\text { 2. Peraturan Presiden } \\
\text { 3. Peraturan Menteri } \\
\text { 4. Kebijakan Adm } \\
\text { Neg }\end{array}$ & $\begin{array}{l}\text { 1. Direktorat PTK- } \\
\text { PNF } \\
\text { 2. LKBH } \\
\text { 3. Asosiasi/Himpunan2 } \\
\text { masing-masing } \\
\text { profesi }\end{array}$ \\
\hline 2 & ETIKA & $\begin{array}{l}\text { 1. } \begin{array}{l}\text { Kode } \\
\text { Pendidik } \\
\text { dipilah } \\
\text { beberapa profesi } \\
\text { khusus) } \\
\text { dlm }\end{array} \\
\text { 2. } \\
\text { Kode Etik Tenaga } \\
\text { Kependidikan } \\
\text { (dapat dipilah } \\
\text { sesuai dg profesi } \\
\text { masing2 bila } \\
\text { diperlukan) } \\
\text { Peraturan } \\
\text { internal/Acara } \\
\text { Penanganan } \\
\text { Masalah Etik } \\
\text { Peraturan ttg } \\
\text { Badan Kehormatan } \\
\text { Etik }\end{array}$ & $\begin{array}{l}\text { 1. Badan Kehormatan } \\
\text { Etik PTK-PNF } \\
\text { 2. LKBH sebagai agen } \\
\text { pelaksana } \\
\text { penegakan etika } \\
\text { PTK PNF } \\
\text { 3. Asosiasi/Himpunan2 } \\
\text { masing-masing } \\
\text { profesi } \\
\text { 4. Asosiasi/Himpunan } \\
\text { Profesi PTK PNF }\end{array}$ \\
\hline
\end{tabular}

\section{Bagan Alir Pedoman Pemberian Bantuan Hukum PTK PNF}

Pemberian bantuan hukum yang efektif dan efisien dapat dilakukan sesuai dengan langkah-langkah prosedural yang terencana. Tanpa adanya langkah-langkah yang jelas sebagaimana yang ditunjukkan dalam sebuah bagan alir, maka tujuan pemberian bantuan hukum itu tidak akan pernah tercapai dengan baik. Demikan pula dengan pemberian bantuan kepada para pendidik dan tenaga kependidikan dalam lingkungan pendidikan non formal 
tetap diperlukan adanya kejelasan bagan alir sebagai pedoman bagi setiap pelaksana atau petugas (pengacara) LKBH dalam melakukan tugasnya.

Pedoman pemberian bantuan hukum dalam bentuk bagan alir penanganan masalah hukum, kasus atau perkara ini dapat menjadi pegangan internal bagi kalangan LKBH dalam melaksanakan tugasnya di lapangan sesuai dengan mekanisme kerja internal yang mungkin telah ada dalam SOP (Standard Operating Procedure) masing-masing kantor LKBH tersebut. Pedoman dalam bentuk bagan alir ini diperlukan untuk menyamakan cara penanganan kasus pada umumnya dengan spesifik yang dihadapi sehubungan dengan profesi PTK PNF. Dalam hal ini kita sudah dapat mengambil beberapa kesimpulan dari kasus-kasus yang ditemukan di lapangan, profesi PTK PNF lebih sering berkaitan dengan bidang hukum administrasi, hukum ketenagakerjaan (perburuhan), hukum hak-hak asasi manusia, dan juga hukum perdata (perikatan) pada umumnya.

\section{A. Konsepsi Pendekatan dan Metode Pendekatan}

Pendekatan yang dipakai dalam membuat pedoman pemberian bantuan hukum dalam bentuk bagan alir ini adalah pendekatan pragmatis yang disesuaikan dengan mekanisme kerja kantor hukum pada umumnya. Hal yang harus dipahami betul oleh kalangan LKBH dan juga pengambil kebijakan dalam lingkup Direktorat PTK PNF adalah soal perlindungan hukum. Perlindungan hukum hanyalah salah satu cara atau mekanisme yang dapat digunakan untuk melindungi profesi PTK PNF. Cara atau mekanisme lainnya adalah perlindungan melalui etika profesi. Sehingga, dapat dijelaskan bahwa perlindungan profesi dapat dilakukan melalui mekanisme hukum dan melalui mekanisme penegakan etika profesi.

Pendekatan pragmatis dalam hal pemberian perlindungan profesi melalui mekanisme hukum itu dilakukan melalui perancangan mekanisme kerja kantor hukum dalam menangani perkara, kasus hukum yang muncul dari kegiatan profesi PTK PNF itu.

Metode Pendekatan yang dilakukan dalam pemberian perlindungan profesi melalui mekanisme bantuan hukum ini lebih dekat kepada metode penanganan kasus hukum secara selektif (Selective approach) yang simpel bagi kebanyakan profesi PTK PNF. Metode Pendekatan ini lebih merupakan suatu deskriptif analisis terhadap kasus-kasus yang datang atau dimohonkan oleh PTK PNF pada umumnya dan yang juga disesuaikan dengan kondisi kantor hukum atau LKBG pada umumnya. Tahapan yang harus dilakukan dalam pemberian bantuan hukum atau penanganan kasus hukum ini 
mencakup 1. adanya permohonan, 2, adanya verifikasi. 3. adanya kualifikasi sebelum akhirnya mencapai tahap akhir 4. penyelesaian kasus.

\section{Bagan Alir Pelaksanaan Pemberian Bantuan Hukum}

Bagan alir pelaksanaan pekerjaan untuk melakukan proses pemberian bantuan hukum ini sebagai upaya untuk menggambarkan tahap-tahap terjadinya proses pembantuan hukum. Tahapan ini dimulai dengan adanya permohonan/ pengaduan dari PTK PNF, kemudian dilakukan verifikasi (pemilahan), klasifikasi kasus berdasarkan perspektif hukum (clear and distinct mechanism), dan kemudian dianalisis untuk diselesaikan.

\section{Tahap Permohonan}

Pada tahap awal selalu dimulai dengan adanya permohonan Bantuan Hukum dari PTK PNF (LKBH akan sangat sulit bila diharapkan untuk pendekatan pro-aktif untuk mencari-cari kasus hingga pada tingkatan kecamatan, sehingga $\mathrm{LKBH}$ bersifat menunggu adanya kasus). Namun demikian LKBH juga dapat menempatkan kotak surat khusus di tingakatan kabupaten dan kecamatan untuk menerima kasus persurat yang kemudian ditindaklanjuti dengan konsultasi, mediasi, dan bila perlu dengan cara advokasi (litigasi) atau dalam bentuk Advokasi/ Pendampingan, menimbang soal Hukum atau Etika, bisa pula bantuan Hukum pro-aktif (Preventif maupun Kuratif) Inisiatif dari Bagian Hukum Depdiknas/Perintah/Instruksi Kerja untuk menyelesaikan kasus hukum dari Menteri, Sekjen, Dirjen, atau Direktur PTK PNF.

\section{Tahap Verifikasi}

Verifikasi dan Klasifikasi Masalah Hukum/Kasus dilakukan pada tahap ini untuk mengetahui secara pasti, pada jenis/kategori hukum apakah masalah yang dimohonkan untuk dipecahkan itu berada, apakah pada bidang hukum ketenagakerjaan, apakah bidang HaKI, atau bidang hukum lainnya, namun mungkin saja itu bukan merupakan masalah hukum, tetapi masalah sosial lain atau masalah psikologis dsb. 


\section{Tahap Kualifikasi}

Untuk tahap kualifikasi ini, persoalan yang masuk/dimohonkan untuk dibahas dipertimbangkan apakah soal yang berat atau ringan, apakah ini perlu jalur litigasi atau non litigasi, apakah ini perlu segera atau memakai jalur mediasi dan negosiasi yang paling efektif. Hal ini menjadi penting karena kesalahan langkah penanganan bisa menyebabkan kasus itu menjadi bias dan tidak terpecahkan.

\section{Tahap Penyelesaian Kasus}

Kasus dianggap selesai apabila sudah menghasilkan apa yang dituntut/diminta dari keadaan yang sebelumnya belum ada.Hal ini bisa diupayakan melalui penanganan perkara secara litigasi/ advokasi, atau mediasi, atau pula setelah melewati proses negosiasi diantara para pihak yang bersengketa.

\section{BAGAN ALIR PEMBERIAN BANTUAN HUKUM BIDANG PENDIDIKAN NON FORMAL}

PERMOHONAN BANTUAN HUKUM DAN INSTRUKSI KERJA :

1. Permohonan Bantuan Hukum dari PTK PNF

2. Bantuan Hukum dalam bentuk Advokasi/Pendampingan

3. Bantuan Hukum dalam menimbang soal Hukum atau Etika

4. Bantuan Hukum pro-aktif (Preventif maupun Kuratif) Inisiatif dari Bagian Hukum Depdiknas

5. Perintah/Instruksi Kerja untuk menyelesaikan kasus hukum dari Menteri, Sekjen, Dirjen, atau Direktur PTK PNF

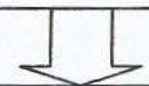

1. PERSIAPAN PEMBERIAN BANTUAN HUKUM

A. Perhatikan Jangka Waktu Permohonan Bantuan dan Instruksi Kerja

B. Identifikasi Masalah/Konflik (kasus)

C. Inventarisasi Data atau Bahan hukum lain

D. Siapkan seluruh informasi hukum yang terkait

E. Siapkan Langkah strategis dan Penanganan Bertahap

2. PELAKSANAAN PEMBERIAN BANTUAN HUKUM
A. Verifikasi dan Klasifikasi Masalah Hukum/Kasus
B. Penanganan Kasus dari awal; Step A-Z
C. Penanganan untuk Kasus yg sedang berjalan; Step A-Z

3. PENYEMPURNAAN APABILA DITEMUKAN HAL-HAL YG PERLU MENDAPAT PERBAIKAN 


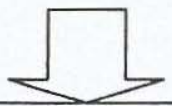

1. Penyelesaian Masalah Hukum secara adil, manusiawi, dan tidak merugikan kepentingan Warga Negara, serta merupakan perwujudan dari maksud, UU HAM, dan UU Sistem Pendidikan Nasional.

2. Terciptanya ketentuan hukum yang partisipatif dan pertimbangan hukum (kebijakan) yang serasi, selaras, dan seimbang dalam mencapai tujuan UU HAM, dan UU Sistem Pendidikan Nasional.

\section{BAGAN ALIR MEKANISME PEMBERIAN BANTUAN HUKUM}

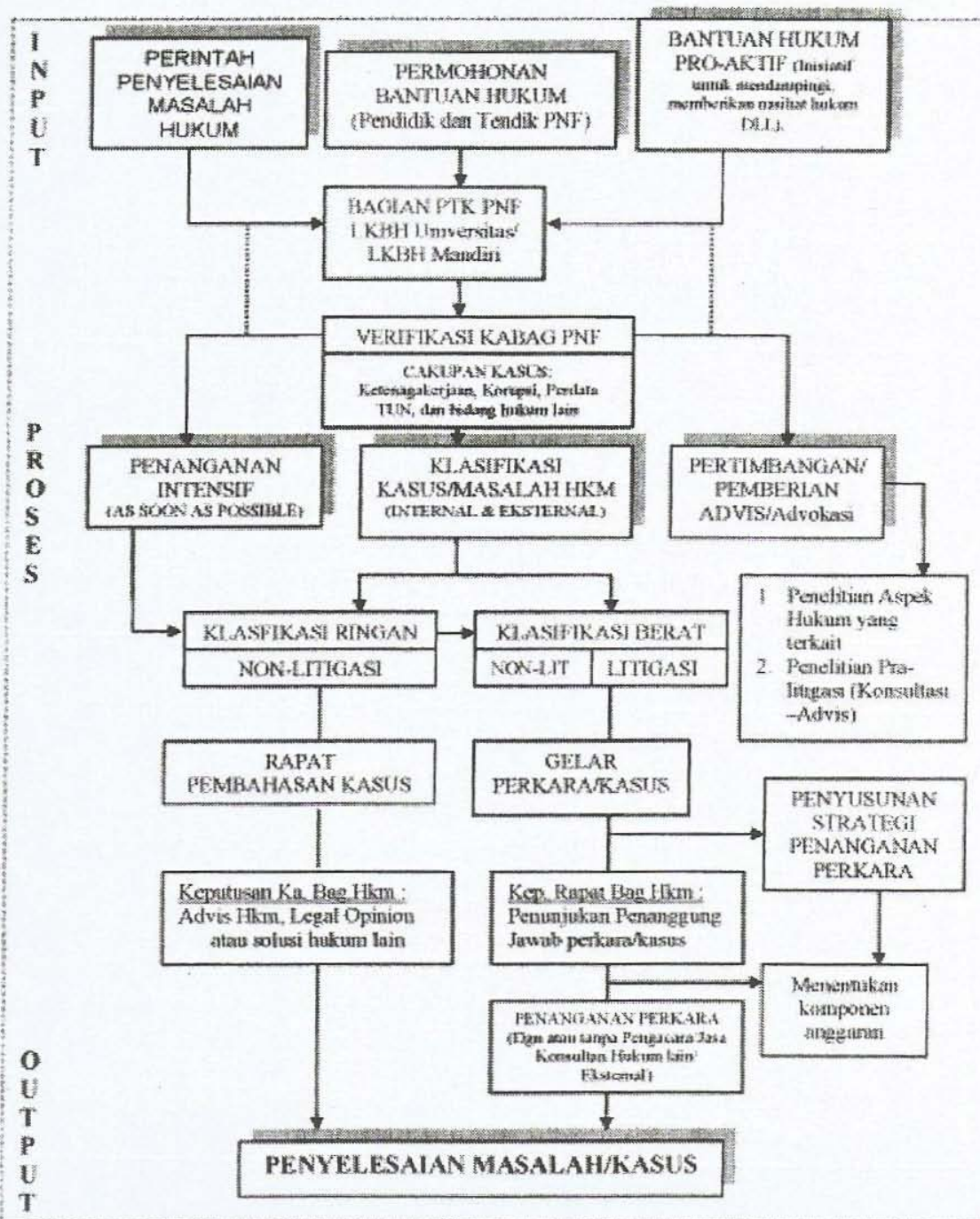




\section{Kesimpulan}

Secara umum dapat disimpulkan, bahwa dari kompilasi kasus hukum yang dikemukakan empat wakil LKBH yang diwawancara/survey, maupun narasumber dari Direktorat PTK PNF sendiri, tidak banyak kasus hukum yang muncul dari kalangan pendidik maupun tenaga kependidikan dalam jalur pendidikan non formal. Artinya, sangat kecil kemungkinan terjadinya kasus hukum yang dapat masuk sampai ke ruang pengadilan (litigasi). Hal ini dapat menggambarkan keadaan yang sama pada LKBH-LKBH di wilayah lainnya di Indonesia (generalisasi). Keadaan seperti ini menunjukkan masih perlunya kegiatan sosialisasi karena memang tidak ada hal yang dapat diangkat untuk diadvokasi (litigasi). Paling tidak hal yang dapat dilakukan adalah mediasi (aktualisasi dalam menyalurkan permasalahan/kasus ke instansi/lembaga terkait dan lobying).

Dari delapan akar permasalahan hukum (lihat bab II) yang dapat memunculkan berbagai kasus hukum dan sosial lainnya, tiga diantaranya adalah berkaitan dengan kebijakan Departemen Pendidikan Nasional dalam mengatur hal-hal yang menyangkut eksistensi PTK PNF. Adapun lima hal lainnya secara langsung maupun tidak langsung berkenaan dengan masalah hukum dan etika yang dapat tidak hanya diperjuangkan oleh LKBH tetapi juga oleh Asosiasi/Himpunan Profesi, dan juga Depdiknas, misalnya soal tidak ada atau tidak memadainya payung hukum yang ada. (Contoh: Belum ada PP Tentang PNFI)

Dalam perspektif ilmu hukum, klasifikasi "perlindungan" yang dimuat dalam UU No. 14 tentang Guru dan Dosen kuranglah tepat. Dalam hubungannya dengan klasifikasi genus dan species, perlindungan profesi itu adalah genusnya, dimana spesies yang termasuk didalamnya adalah perlindungan hukum, dan perlindungan etika. Di dalam perlindungan hukum itu ada lagi perlindungan K3 (Kesehatan dan Keselamatan Kerja), serta perlindungan Hak atas Kekayaan Intelektual (HAKI/HKI), dan perlindungan dalam bidang hukum lainnya. Semua itu dimaksudkan untuk perlindungan profesi, dalam hal ini adalah profesi PTK PNF tentunya.

Namun demikian, harus kita pahami bahwa pendidik dan tenaga kependidikan ini adalah juga merupakan karakter profesi yang memerlukan kode etik tersendiri. Oleh sebab itu dapat dinyatakan bahwa perlindungan profesi itu dilakukan melalui perlindungan hukum dan perlindungan etika (kode etik profesi). Sehinga untuk perlindungan melalui jalur hukum diperlukan perangkat hukum yang memadai, demikian pula perlindungan melalui jalur etika memerlukan perangkat etika yang berupa kode etik, dimana badan kehormatan etik sebagai lembaga yang menegakkan adanya pelanggaran kode etik tersebut. 
Metode Pendekatan untuk menggambarkan bagan alir bantuan hukum lebih merupakan suatu deskriptif analisis terhadap kasus-kasus yang datang atau dimohonkan oleh PTK PNF pada umumnya dan yang juga disesuaikan dengan kondisi kantor hukum atau LKBH pada umumnya. Tahapan yang harus dilakukan dalam pemberian bantuan hukum atau penanganan kasus hukum ini mencakup: 1 . adanya permohonan, 2. adanya verifikasi, 3. adanya kualifikasi sebelum akhirnya mencapai tahap akhir, 4. penyelesaian kasus. $\mathrm{Hal}$ ini disusun dalam suatu bagan alir yang dapat terlihat jelas alur kerja dari pelaksanaan pemberian bantuan hukum tersebut. Bagan alir ini dapat menjadi pegangan/pedoman yang terbaca jelas bagi PTK PNF maupun bagi pegawai LKBH yang bersangkutan. Sehingga alur pembahasan kasus menjadi lebih jelas dan terkendali.

\section{GAMBAR \\ GAMBAR 1 POLA PIKIR}

Pola pikir merupakan aspek dasar pemahaman yang akan menjadi acuan lebih lanjut dalam melaksanakan pekerjaan secara keseluruhan, sesuai dengan pemahaman dan pendekatan substansial yang dilakukan oleh pihak Peneliti/Konsultan. Pola pikir diawali dengan kegiatan kajian konseptual berkaitan dengan peraturan perundang-undangan bidang pendidikan dengan obyek utama adalah Undang-undang Nomor 20 Tahun 2003 tentang Sisitem Pendidikan Nasional. Kegiatan selanjutnya adalah inventarisasi dan kajian terhadap peraturan perundang-undangan lainnya yang terkait dengan bidang pendidikan non formal dan perlindungan bagi pendidik dan tenaga kependidikannya.

Dari kegiatan tersebut selanjutnya akan terinventarisasi berbagai permasalahan bidang pendidikan non formal, namun hal ini masih bersifat umum dan teoritis. Berbagai permasalahan/kasus/ konflik yang berkenaan dengan pendidikan non formal tersebut kemudian dikompilasi dari kasus-kasus yang paling sering muncul di wilayah/daerah, kemudian dikaji dan menentukan alternatifalternatif penanganannya melalui suatu lembaga dan pedoman.

Dalam rangka penguatan konsep, selanjutnya dilakukan diskusi dengan nara sumber dan pakar, serta para pemangku kepentingan lainnya (Ketua dan advokat di LKBH-LKBH), diharapkan dapat memberikan masukan, saran dan tanggapan baik secara konseptual maupun teknis yang selanjutnya akan 
diabstraksikan dalam struktur Konsep. Adapun pola pikir penyusunan kasus-kasus (kompilasi) serta pedoman pemberian bantuan hukum bidang pendidikan non formal tersebut, dapat dilihat pada Gambar 1.

\section{Gambar 1}

Pola Pikir Identifikasi/Kompilasi Kasus-kasus Hukum dan Bagan Alir Dalam Perlindungan Hukum Bidang Pendidikan Non Formal Bagi Pendidik dan Tenaga Kependidikan

\section{Perrosiatan}

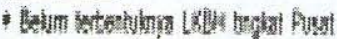

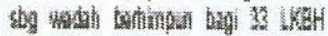

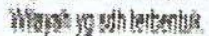

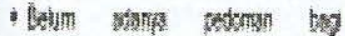

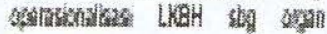

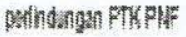

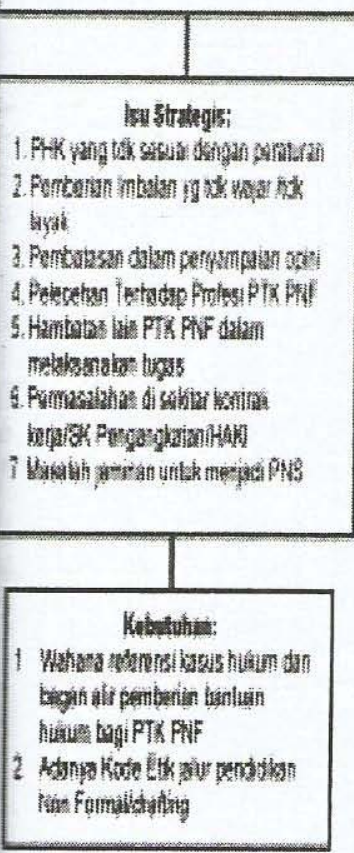

|ât

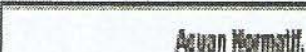

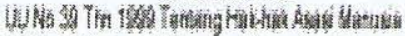

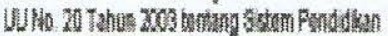

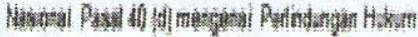

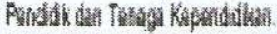

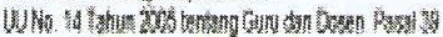

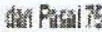

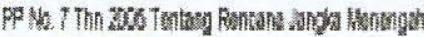
Hotallow

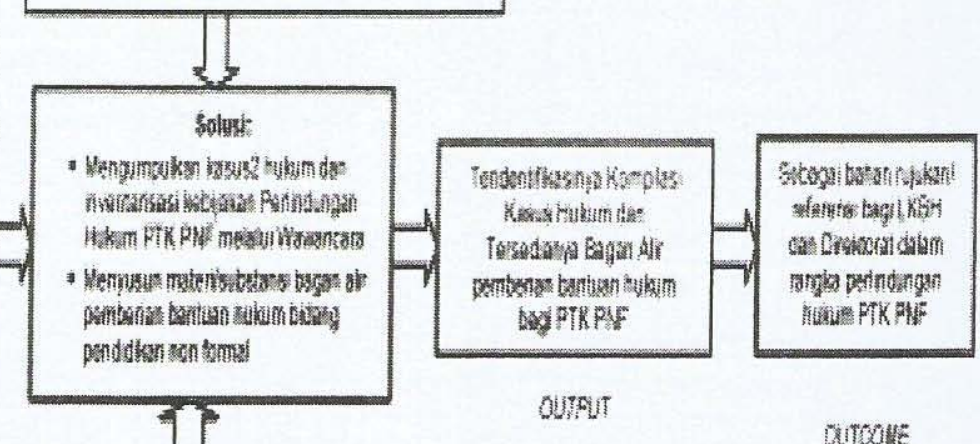

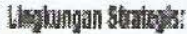

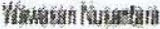

- Hencyis Het

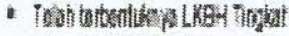
Wars disoforits

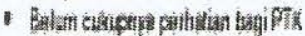

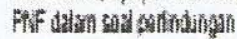

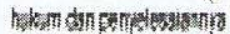




\section{Gambar 2}

Skema Pendekatan Dan Metodologi Identifikasi/Kompilasi Kasus-Kasus Hukum (LKBH) Sebagai Upaya Perlindungan Hukum Bidang Pendidikan Non Formal Bagi Pendidik dan Tenaga Kependidikan

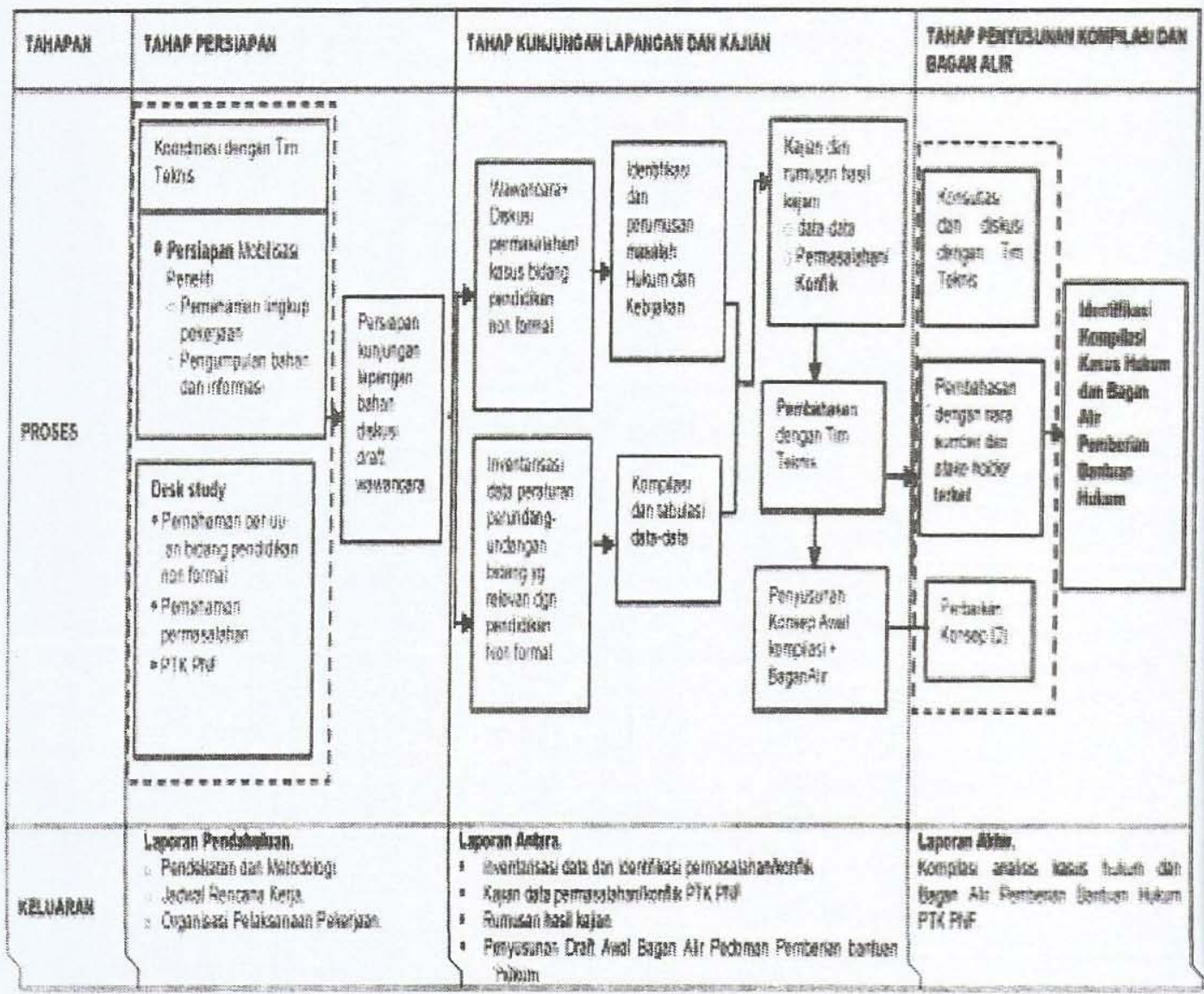

Gambart

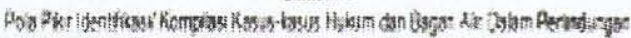

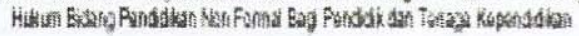




\section{Daftar Pustaka}

Burton, Steven J. An Introduction to Law and Legal Reasoning, Second ed. Boston: Little, Brown and Company, 1995.

Farejohn, John, Jack N. Rakove, dan Jonathan Riley, eds. Constitutional Culture and Democratic Rule. Cambridge: Cambridge University Press, 2001.

Hapsari, Melati Indah. Pengembangan dan Peningkatan Kinerja Pamong Belajar Sanggar Kegiatan Belajar, Jurnal Ilmiah VISI PTK-PNFVol.3, No.2, 2008.

Kuntoro, Sodiq A. Pengembangan Paradigma Baru Keilmuan dan Kelembagaan Pendidikan Nonformal, Jurnal Ilmiah VISI PTK-PNFVol.3, No.1, 2008.

Puspita, Widya Ayu. Pembinaan PTK-PNF Sebagai Upaya Peningkatan Kualitas SDM, Jurnal Ilmiah VISI PTK-PNF - Vol. 2, No.1- 2007.

Rasyid, Harun Al. Membangun Karakter PTK-PNF melalui Peningkatan Kompetensi Personal dan Sosial, Jurnal IImiah VISI PTK-PNF- Vol.3, No.1, 2008.

Samosir, Chairudin. Tutor Inti Sebagai Solusi Percepatan Peningkatan Kompetensi Tenaga Pendididk Nonformal, Jurnal Ilmiah VISI PTKPNF- Vol.3, No.2, 2008.

Sen, Amartya. Demokrasi Bisa Memberantas Kemiskinan (Terjemahan dari Beyond the Crisis: Development Strategies in Asia). Bandung: Mizan, 2000.

Sursam. "Peningkatan Kemampuan Pendidik Pendidikan Nonformal dalam Implementasi Pembelajaran", Jurnal Ilmiah VISI PTK-PNF, Vol.3, No.2, 2008.

Waspodo, Muktiono. "Peran PTK-PNF dalam Menghadapi Keragamaan Sosial Budaya (Sebuah Perenungan Seabad Kebangkitan Nasional)", Jurnal Ilmiah VISI PTK-PNF, Vol.3, No.1, 2008.

Yuhety, Harina et.al., "Indikator Mutu Program Pendidikan Sepanjang Hayat", Jurnal Ilmiah VISI PTK-PNF, Vol.3, No.2, 2008.

Zubair, Achmas Charris. Kuliah Etika, Jakarta: Rajawali Pers, 1990. 